\title{
Epigenetic abnormalities of the mannose-6-phosphate/ IGF2 receptor gene are uncommon in human overgrowth syndromes
}

\author{
C Gicquel, J Weiss, J Amiel, V Gaston, Y Le Bouc, C D Scott
}

J Med Genet 2004;41:e4 (http://www.jmedgenet.com/cgi/content/full/41/1/e4)

$\mathrm{O}$ vergrowth syndromes (OGS) comprise different disorders with overlapping phenotypes. They demonstrate a variety of features, including pre- and postnatal overgrowth, macroglossia, organomegaly, abdominal wall defects, and hypoglycaemia. They also predispose to the development of embryonic tumours (most commonly Wilms' tumour). ${ }^{1}$ The pathogenesis of two different OGS is well established. Beckwith-Wiedemann syndrome (BWS; OMIM $\# 130650$ ) is related to genetic or epigenetic changes in the imprinted $11 \mathrm{pl} 5$ region resulting in an increased level of IGF2 (reviewed by Maher \& Reik $^{2}$ ). Simpson-Golabi-Behmel syndrome (SGBS; OMIM \#312870) is an X linked disease attributed to mutations in the glypican-3 gene (GPC3), which encodes an extracellular proteoglycan believed to interact with insulin-like growth factor II (IGF2) ${ }^{34}$ and/or other growth factors. ${ }^{56}$

The proliferative effects of IGF2 are mediated by the type 1 IGF receptor. In contrast, the mannose-6-phosphate/IGF2 receptor (IGF2R) has an anti-proliferative function, by ensuring the clearance and inactivation of IGF2.7 This function of IGF2R is well supported by knockout mouse models; mice lacking functional IGF2R (KO-IGF2R) are up to $30 \%$ larger than their wild type littermates. ${ }^{8-10}$ The increased growth of KO-IGF2R mice can be attributed to higher IGF2 levels because this phenotype is corrected in KO-IGF2R mice that also lack functional IGF2 or IGF1R. ${ }^{9}{ }^{10}$

IGF2R is developmentally regulated and its expression is maximal during fetal development and organogenesis. ${ }^{11}$ Its expression pattern correlates with that of the IGF2 and GPC3 genes. ${ }^{12-14}$ In the mouse, $I G F 2 R$ is subject to parental imprinting with a maternal specific expression, and this pattern is maintained throughout development and in all somatic tissues in the adult. ${ }^{16}$ In humans, the imprinting status of IGF2R is controversial. Some data are supportive of a polymorphic imprinting that occurs in the pre-term postimplantation embryo in $25-50 \%$ of individuals ${ }^{17-19}$ (reviewed by Wutz et $a^{20}$ and Wutz \& Barlow ${ }^{21}$ ). However, other data suggest that $I G F 2 R$ is not imprinted in primates, including humans. ${ }^{22}$

Human and mouse $I G F 2 R$ genes contain two differential methylated regions (DMRs). DMRl in the IGF2R promoter is differentially methylated only in mice whereas DMR2, in intron 2, is specifically methylated on the maternal allele in both mice and humans. ${ }^{23-25}$ DMR2 acts as a promoter for an antisense RNA that is also imprinted in mice, with expression from the paternal allele. ${ }^{26}{ }^{27}$ The function of the antisense RNA is not completely understood but the deletion of the paternal DMR2 restores biallelic expression of the sense IGF2R transcript, consistent with an expression competition model. ${ }^{26}$

In humans, IGF2R has been implicated as a tumour suppressor gene in various human tumours such as breast ${ }^{28} 29$ and hepatocellular carcinomas ${ }^{30-32}$ and choriocarcinomas. ${ }^{33} 34$

\section{Key points}

- Overgrowth syndromes (OGS) in humans include the extensively studied Beckwith-Wiedemann syndrome (BWS) and Simpson-Golabi-Behmel syndrome (SGBS), which have overlapping phenotypes. The most frequent, BWS, results from various genetic or epigenetic modifications of imprinted genes in the 11 p15 chromosomal region. SGBS is an $X$ linked syndrome involving mutation in the glypican-3 gene, which encodes a heparan sulfate proteoglycan. In both syndromes, the crucial genetic defect is responsible for an increased availability in insulin-like growth factor II (IGF2) or other growth factors.

- The mannose-6-phosphate/IGF2 receptor (IGF2R) has an anti-proliferative function and ensures the clearance and inactivation of IGF2. The IGF2R gene is imprinted in the mouse and its disruption results in overgrowth in mice. Furthermore, epigenetic modifications of IGF2R lead to fetal overgrowth in sheep.

- The aim of this study was to evaluate the role of IGF2R in OGS. Among a series of 152 patients referred to our department for OGS, 55 (36.2\%; 30 males and 25 females) did not exhibit abnormalities at the $11 \mathrm{p} 15$ locus (BWS) and were included in this study. We analysed the expression of IGF2R and the methylation status of two differential methylated regions (DMRs) of the IGF2R gene in this series of 55 OGS patients (30\% with a severe form and $70 \%$ with a mild form). One in 55 patients exhibited a partial demethylation of DMR2, indicative of a mosaicism. This pattern was found in different tissues (blood, skin fibroblasts, and tonsils). The partial demethylation of DMR2 was associated with a slight decrease in the soluble form of IGF2R in plasma and with a decrease in IGF2 binding.

- We show here that although IGF2R is not frequently involved in human OGS, it may play a role in a subset of cases.

Recently, it has been shown that pre-implantation embryo procedures in sheep may result in an inappropriate epigenetic modification in the imprinted IGF2R gene during early embryogenesis and the demethylation of DMR2, leading to downregulation of the receptor and consequently to OGS. ${ }^{35}$

Abbreviations: BWS, Beckwith-Wiedemann syndrome; DMR, differential methylated region; OGS, overgrowth syndromes; SGBS, Simpson-Golabi-Behmel syndrome 
We and others have described that about $70 \%$ of patients referred with OGS exhibit abnormalities at the $11 \mathrm{pl} 5$ imprinted locus, mostly epigenetic modifications. ${ }^{36-40}$ Other mechanisms may induce an overgrowth syndrome by inducing the activity of growth factors such as IGF2. Indeed, we have also shown that about $10 \%$ of male patients without abnormalities in the 11 pl5 region exhibited mutation in GPC3 (unpublished data). Alternatively, other IGF2 related regulatory genes, such as IGF2R, are also good candidates for causing OGS.

The principal aim of this study was to evaluate the role of IGF2R in OGS by analysing the expression and the methylation status of the IGF2R gene in a series of OGS patients with no abnormalities in the $11 \mathrm{p} 15$ region or GPC3. We show here that although IGF2R is not frequently involved in human OGS, it may play a role in a subset of cases.

\section{MATERIALS AND METHODS \\ Patients}

From a series of 152 patients referred to our department for OGS, $92(60.5 \%)$ exhibited an abnormality at the 11 pl5 locus. Most had an epigenetic defect: isolated demethylation of KvDMRI $(\mathrm{n}=52)$ or isolated hypermethylation of the H19 gene $(n=13)$. Twenty-five patients exhibited a genetic defect, $11 p 15$ uniparental disomy $(\mathrm{n}=22)$ and germline CDKNIC mutation $(\mathrm{n}=3)$. Two patients had an llp chromosomal abnormality. GPC3 mutations were found in five cases.

The $55(36.2 \%)$ remaining patients (30 males and 25 females) were included in this study. Informed consent for access to the collected information was obtained from all patients (or their parents) in accordance with national ethics regulations.

Patients were assigned to two groups according to their phenotype. Group 1: severe form of OGS $(n=16)$. These patients presented with at least three of the following four major signs: macrosomia, macroglossia, organomegaly, or abdominal wall defect associated with other clinical features such as neonatal hypoglycaemia, ear abnormalities, or facial naevus flammeus. Four patients had heart disease. Group 2: mild form of OGS $(n=39)$. These patients presented with less than three of the four major signs. Six had heart disease.

\section{Inheritance}

Two of the 55 patients had a monozygotic twin who also exhibited an OGS. One female patient had three brothers and one sister with OGS.

\section{Control subjects}

Plasma and DNA samples from, respectively, 57 ( 55 children) and 25 healthy subjects were used as controls.

\section{Methods}

\section{DNA analysis}

DNA was extracted from leukocytes (all patients) and tissues $(\mathrm{n}=7$ : tongue tissue obtained from tongue resection for macroglossia $(\mathrm{n}=3)$, normal kidney $(\mathrm{n}=1)$, peritumoural liver $(\mathrm{n}=1)$, and tumours $(\mathrm{n}=2))$, as previously described ${ }^{41}$ Parental leukocyte DNA was available for $51 \%$ of the patients.

\section{Allele specific methylation of DMR 1 and DMR2 of the IGF2R gene}

DMR1 and DMR2 methylation status was assessed by Southern blotting and by methylation specific PCR after bisulphite treatment.

For the Southern blot, briefly, genomic DNA was digested with HindIII and then with the methylation sensitive enzyme HpaII or its non-methylation sensitive isochizomer MspI. Digested samples were subjected to electrophoresis in $1 \%$ agarose gels, blotted onto GeneScreen Plus membranes (NEN
Life Science Products, Boston, MA, USA), and hybridised with DMRl or DMR2 probes.

The DMR1 and the DMR2 probes were obtained by PCR. The $5^{\prime}$ sense primer DMRIS (5'-CAGCTGGCCTAGTGT GGTTGAA-3'), and the $3^{\prime}$ antisense primer DMRIAS (5'TGGCAGATTTGTCATCCTAAGA-3') amplify a $400 \mathrm{bp}$ fragment in the DMRl region (GenBank accession no. AF348209, nt 2016-2415). The $5^{\prime}$ sense primer DMR2S (5'CATGCGCCTCCAGCTGCGCATCTC-3') and the $3^{\prime}$ antisense primer DMR2AS (5'-GCTGATCCAATCCCATATACACCT-3') amplify a 410 bp fragment in the DMR2 region (GenBank accession no. X83701, nt 3012-3419).

For the combined bisulphite restriction analysis of DMR2, briefly, after a first step of alkaline denaturation, genomic DNA ( $1 \mu \mathrm{g}$ ) was deaminated by sodium bisulphite overnight at $55^{\circ} \mathrm{C}$. DNA was desalted using the Wizard Clean-up system (Promega, Madison, WI, USA), desulphonated for $30 \mathrm{~min}$ at $37^{\circ} \mathrm{C}(0.3 \mathrm{~mol} / \mathrm{l} \mathrm{NaOH})$ and precipitated. ${ }^{42}$ The bisulphite treated DNA was PCR amplified with the $5^{\prime}$ sense primer $5^{\prime}$ GGTATGTTGGGGATAGGTTTTGGGAGTTG- $3^{\prime}$ and the $\gamma \mathrm{P}^{32}$ labelled 3' antisense primer 5'-CAAACACACTAACAACCA CTACATCCCTC-3'. PCR products were then digested with the methylation sensitive enzyme BstUI. After treatment by bisulphite, the demethylated allele $(217 \mathrm{bp})$ loses this restriction site and is not cut by BstUI. The digested samples were subjected to electrophoresis in SDS/10\% PAGE.

IGF1, IGF2, soluble IGF2R assays in plasma Plasma samples were available for 16 patients (eight patients from each group) and 55 control children. The soluble form of IGF2R (sIGF2R) was determined by ELISA as previously described. ${ }^{43}$ IGF2 and IGF1 were assessed by RIA as previously described. ${ }^{44} 45$

\section{Superose- 12 gel chromatography, IGF2 binding} assay, and affinity labelling of IGF2R

Plasma samples $(200 \mu \mathrm{l})$ were loaded onto a Superose-12 gel permeation column (Pharmacia Biotech, Uppsala, Sweden) eluting at $1 \mathrm{ml} / \mathrm{min}$ in PBS. Fractions $(0.5 \mathrm{ml})$ were collected and the column was washed between runs. The elution of the sIGF2R in fractions 19-21 was confirmed by ELISA, Western immunoblotting and by IGF2 affinity labelling.

The IGF2 binding assay was performed by incubating $150 \mu \mathrm{l}$ of fractions 12 to 34 in the presence of ${ }^{125} \mathrm{I}$ IGF2 (8000-10 $000 \mathrm{cpm})$ in $25 \mathrm{mmol} / \mathrm{l}$ Hepes $\mathrm{pH} 7.4,0.1 \%$ BSA, and $0.1 \%$ Triton X-100. After an overnight incubation at $4{ }^{\circ} \mathrm{C}$, IGF2 binding complexes were precipitated by centrifugation after addition of $10 \mu \mathrm{l} \%$ gammaglobulin (Sigma, St Louis, MO, USA) and $1 \mathrm{ml}$ of $18 \%$ PEG $6 \mathrm{~K}$. The pellet was counted in a gamma counter.

Affinity labelling of IGF2R: $20 \mu \mathrm{l}$ of pooled fractions 19-21 were incubated with ${ }^{125}$ I IGF2 $(100000 \mathrm{cpm})$ for 16 hours at $4^{\circ} \mathrm{C}$ and the samples were then incubated with $0.5 \mathrm{mmol} / \mathrm{l}$ BS3 (Pierce, Rockford, USA) for 30 minutes at room temperature. The reaction was stopped with Laemmli buffer and $4 \% \beta$ mercaptoethanol, and samples were submitted to SDS $/ 6 \%$ PAGE. The gel was stained and dried before autoradiography.

Densitometry and calculation of the methylation index of DMR2

Blots were analysed with a Storm PhosphorImager (Molecular Dynamics, Inc, Sunnyvale, CA, USA). The methylation index of DMR2 was assessed by densitometry of autoradiographs and calculated as the ratio of the intensity of the methylated band to the sum of the methylated and unmethylated band intensities. 


\section{RESULTS}

DMR 1 and DMR2 methylation analysis in blood samples and tissues

DMRl methylation analysis was performed in 25 control subjects and 55 OGS patients. Southern blot analysis showed only one band of $2.6 \mathrm{~kb}$ after digestion with HindIII and HpaII, confirming that the maternal and the paternal alleles were not differentially methylated ${ }^{25}$ (fig 1A).

For DMR2, Southern blot analysis of leukocyte DNA from control subjects showed two bands $(2.1$ and $3.1 \mathrm{~kb})$ of equal intensity after digestion with HindIII and HpaII, indicating that the two parental alleles were differentially methylated (fig 1B). DMR2 has been previously shown to be hypermethylated on the maternal allele. ${ }^{25}$ DMR2 methylation index was normal, at between 46.6 and $52.6 \%$ (mean (SD) 49.5 (1.8)\%).

The pattern of DMR2 methylation in leukocyte DNA was normal for 54 of 55 OGS patients with methylation indexes varying between 46.3 and 53.3\% (mean (SD) 49.8 (1.5)\%). This pattern was also normal in the seven tissues analysed.

One of the 55 patients (patient 14, group 2) exhibited a partial demethylation of DMR2 in blood cells. Skin fibroblasts and tonsil tissues were also available for this patient and the demethylation pattern was the same as in blood cells, with methylation indexes of $31 \%, 40 \%, 32 \%$, and $36 \%$ in respectively blood cells, skin fibroblasts, and left and right tonsils (fig 1B). Both parents had normal methylation patterns (fig 1B). Combined bisulphite restriction analysis confirmed this partial demethylation pattern (fig IC).

\section{Analysis of the soluble form of IGF2R (sIGF2R) in plasma samples}

Plasma levels of sIGF2R were assessed in 57 ( 55 children) control subjects and 16 ( 15 children) patients with OGS (fig 2A). Most patients had levels in the normal range for age, although three had levels below this. Patient 14 had a decreased sIGF2R level $(0.57 \mu \mathrm{g} / \mathrm{ml}$; normal for age 1.12 $(0.28) \mu \mathrm{g} / \mathrm{ml}$ ) compared with patients of the same age ( 3 years). However, IGF1 and IGF2 plasma levels were in the normal range (figs $2 \mathrm{~B}$ and $2 \mathrm{C}$ ). As in control subjects, IGF 1 levels in OGS patients increased with age through puberty.

\section{IGF2 binding assay after Superose-12 gel chromatography}

Superose-12 gel chromatography was performed for 13 patients (six patients from group 1 and seven patients from group 2) and compared with samples from age matched control subjects.
IGF2 binding assay after superose-12 gel chromatography of plasma from control subjects showed three binding peaks. SIGF2R elutes in fractions 19-22 as shown by ELISA (fig 3A), Western immunoblotting, and IGF2 affinity labelling (fig 3B). The IGF2 binding activity eluting in fractions 23-28 correspond to IGFBPs as previously reported ${ }^{46}$ and shown by Western ligand blotting (fig 3B).

Patient 14, with partial demethylation of DMR2, exhibited a $40 \%$ decrease in IGF2 binding of fractions 19-21 when compared with control subjects (three different control subjects (fig 4A). This decrease in IGF2 binding was reflected by a similar decrease in sIGF2R levels (fig 4B). Affinity labelling of IGF2R in pooled fractions 19-21 with ${ }^{125}$ I IGF2 was decreased to a similar extent (fig 4C).

\section{DISCUSSION}

Experiments in mice and additional findings in humans have increasingly linked the IGF system, and more particularly IGF2, directly to OGS. IGF2 levels are increased and mice are larger when the paternally imprinted $H 19$ gene is deleted ${ }^{47}$ or when IGF2R is disrupted. ${ }^{8-10}$ These effects are very probably attributable to excessive IGF2 function, because a further knockout of IGF2 in IGF2R or H19 deficient animals rescues the phenotype. ${ }^{9}{ }^{10} 47$ Perhaps more striking is the production of a set of phenotypes quite reminiscent of SGBS or BWS in transgenic mice with an additional copy of $I G F 2 .^{48}$

OGS such as BWS and SGBS exhibit overlapping phenotypes, and molecular analysis has already led to diagnosis of SGBS in patients initially considered as BWS. In both syndromes, the fetal overgrowth is, at least partially, related to increased availability in IGF2. Molecular abnormalities of the 11 p15 imprinted region or the GPC3 gene account for about $75-80 \%$ of patients referred for OGS.

The crucial role of IGF2 for fetal growth and the function of IGF2R in the clearance of IGF2 justified a study of the putative involvement of IGF2R in patients without genetic or epigenetic abnormalities in the $11 \mathrm{pl} 5$ region. This hypothesis was recently strengthened by the description of epigenetic abnormalities of IGF2R resulting in abrogation of IGF2R expression in cloned sheep with large offspring syndrome. ${ }^{35}$

IGF2R imprinting is still controversial in humans. IGF2R was initially reported to be expressed from both parental alleles. ${ }^{49} 50$ However, subsequent studies brought evidence that IGF2R is a polymorphic trait in humans and that IGF2R is imprinted during early development in $25-50 \%$ of fetuses. ${ }^{17}{ }^{18}$ More recently, Oudejans et al ${ }^{19}$ confirmed IGF2R imprinting in $50 \%$ of first trimester placental tissues. In contrast to the mouse, ${ }^{51}$ they failed to detect AIR RNA

A

B
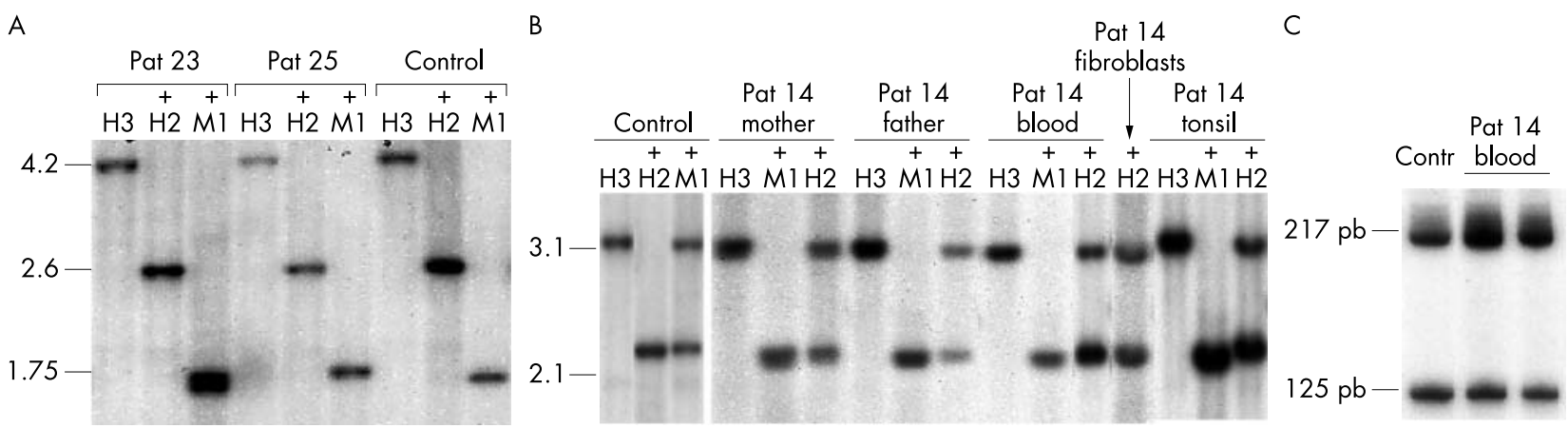

Figure 1 Methylation analysis of DMR1 and DMR2 of IGF2R in patients with overgrowth syndromes. (A) DMR1 methylation was assessed by Southern blotting after digestion with Hindlll (H3), Hindlll + Hpall $(+\mathrm{H} 2)$ and Hindlll+Mspl $(+\mathrm{M} 1)$. The $4.2 \mathrm{~kb}$ Hindlll fragment is fully cut with Hpall resulting in a $2.6 \mathrm{~kb}$ fragment, indicating that DMR1 is fully demethylated. (B) DMR2 methylation was assessed by Southern blotting after digestion with Hindlll (H3), Hindlll + Hpall $(+\mathrm{H} 2)$ and Hindlll + Mspl $(+\mathrm{M} 1)$ of leukocyte DNA from a control subject, patient 14, and the parents of patient 14 (as well as skin fibroblasts and tonsil from patient 14). DMR2 is partially demethylated in the different samples from patient 14. (C) DMR2 methylation was assessed by combined bisuphite restriction analysis. After bisulphite treatment, DNA was amplified by PCR (see methods) and digested with the methylation sensitive enzyme BstUl. The $217 \mathrm{bp}$ fragment is the demethylated fragment and the $125 \mathrm{bp}$ fragment is the methylated fragment. 

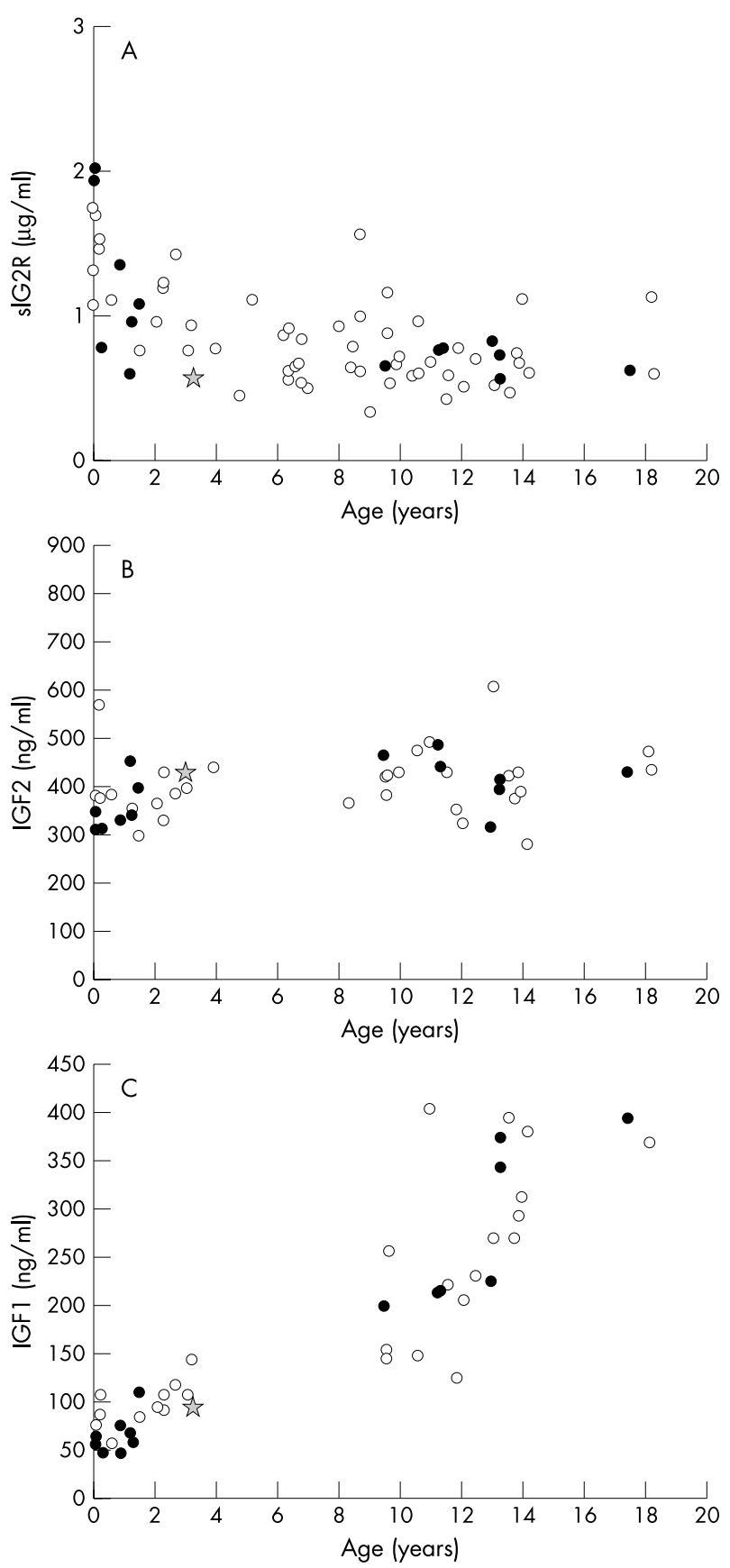

Figure 2 sIGF2R (A), IGF2 (B), and IGF1 (C) levels in normal subjects (white circles) and patients with OGS (black circles). Patient 14, with partial demethylation of DMR2, is indicated by a grey star.

(antisense transcript) in human tissues, even in samples that downregulate IGF2R expression in an allele specific manner. However, a more recent study, analysing different species, reported that in contrast to most imprinted genes, the imprinting of $I G F 2 R$ is not conserved between mammals and that virtually all primate mammals possess two activated copies of IGF2R. ${ }^{22}$

Until recently, the human DMR2 was considered as fulfilling the criteria for an imprinting box. However, Killian et $a^{22}$ also showed that the existence of a DMR in intron 2 is not essential for the imprinting of IGF2R (marsupial opossum) and that a DMR in intron 2 can exist independently of the imprinting of IGF2R (human).

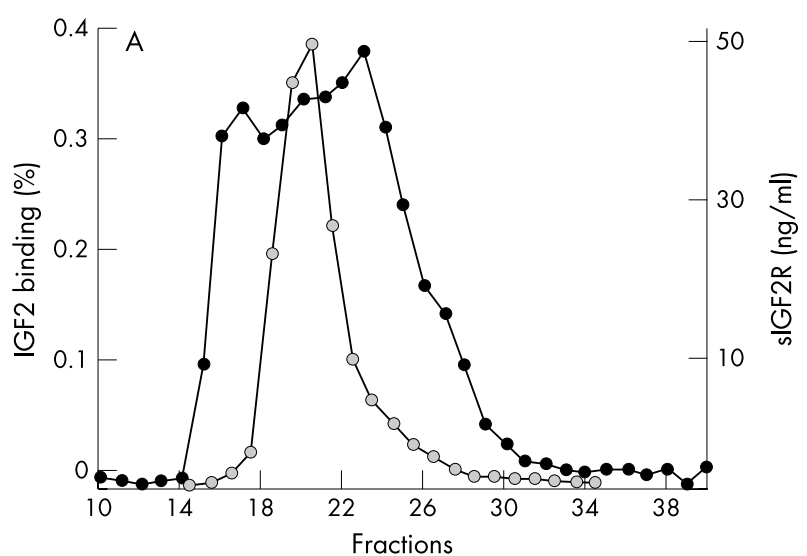

B

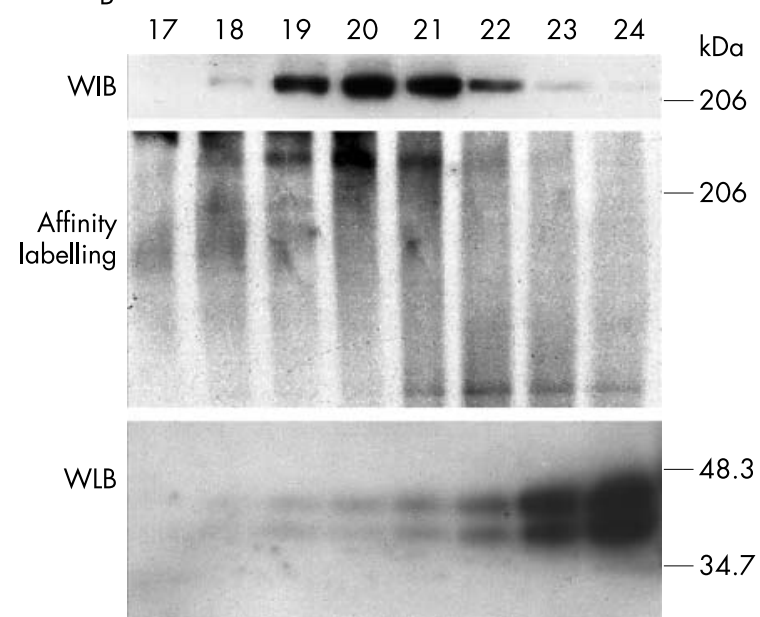

Figure 3 (A) IGF2 binding assay (black symbols) and sIGF2R levels (grey symbols) in Superose-12 gel chromatography fractions of plasma from a normal subject. (B) Western immunoblotting with a polyclonal anti-IGF2 receptor antibody, IGF2 affinity labelling, and Western ligand blotting of Superose-12 gel chromatography fractions of plasma from a normal subject.

Abnormal imprinting of $I G F 2 R$ has been reported only once in humans. Xu et al $l^{52}$ showed that $50 \%$ of Wilms' tumours, a very frequent tumour in OGS, exhibited an abnormal imprinting pattern of $I G F 2 R$ with marked repression of the paternal allele. However, these data were not confirmed by Killian et al.22

The data shown here do not support the hypothesis that the downregulation of IGF2R is a frequent cause of OGS in humans. Indeed, from 55 patients with OGS and with a normal analysis at the $11 \mathrm{pl} 15$ locus, only one patient exhibited abnormalities of IGF2R both at the DNA and protein levels. The phenotype of this patient was mild with moderate statural advance, macroglossia, and hemihyperplasia. It was very different from phenotypes exhibited by IGF2R deficient mice or by cloned sheep but, in these two models, the defect was responsible for a complete abrogation of IGF2R. Indeed, when reported in sheep, ${ }^{35}$ the demethylation of DMR2 was complete. In contrast, patient 14 exhibited a partial demethylation of DMR2 that was found in different tissues. The fact that the demethylation of DMR2 was partial is not surprising. In a study of demethylation of the KCNQIOT gene (11p15 locus) in BWS, we previously showed that at least one third of patients exhibited a partial demethylation, suggesting that this abnormality can occur as a mosaicism with variable tissue distribution. ${ }^{38}$ The mosaic distribution may also explain the hemihyperplasia in patient 14. The 

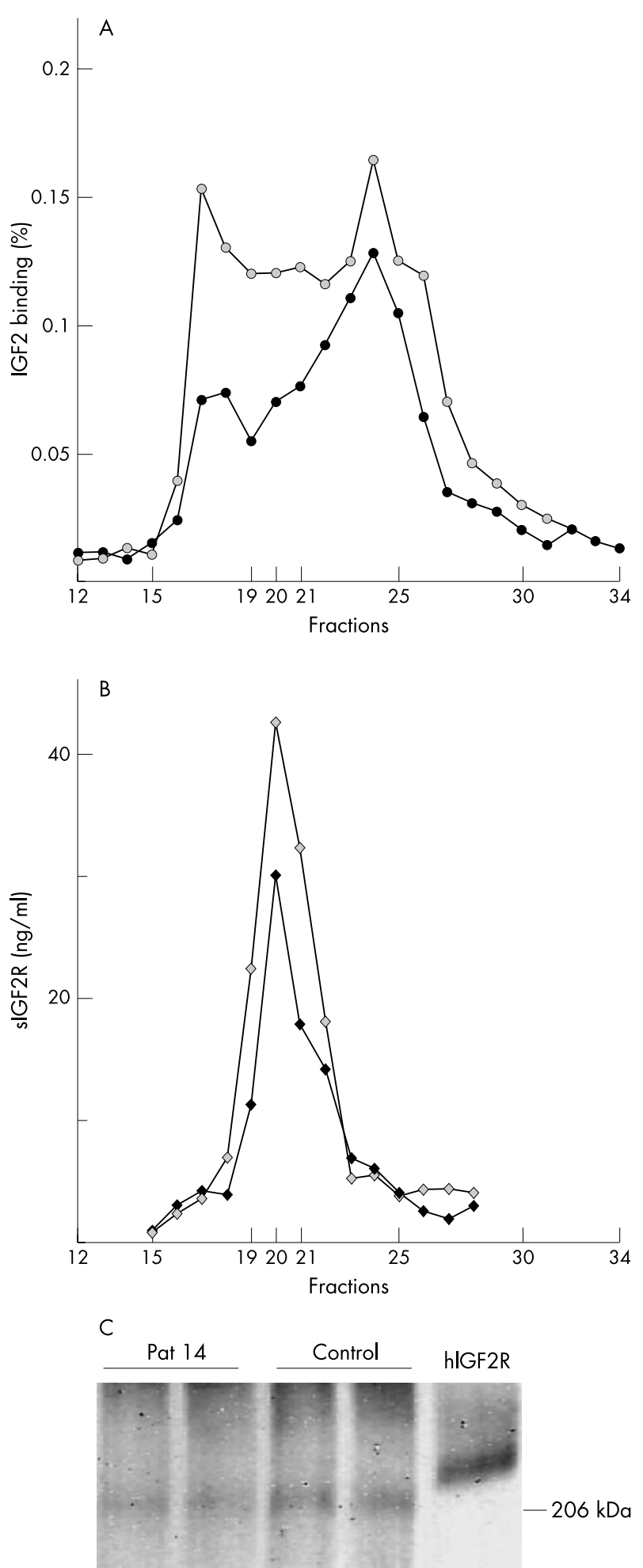

Figure 4 IGF2 binding assay (A) and sIGF2R levels (B) after Superose12 gel chromatography of plasma from patient 14 (black symbols) and a representative age matched control subject (grey symbols). (C) Affinity labelling of IGF2R of pooled fractions 19-21 incubated with ${ }^{125}$ I IGF2 (in duplicates) after Superose-12 gel chromatography of plasma from patient 14 and a representative age matched control subject. The hIGF2R used as a control is a purified membrane receptor and is therefore larger than truncated circulating protein.

partial demethylation of DMR2 in patient 14 was shown with two different techniques (Southern blotting and combined bisulphite restriction analysis) and in three different tissues.
It is noteworthy that this pattern was not more obvious in skin fibroblasts taken from the side of the body with hemihyperplasia.

When the expression and the functionality of IGF2R were analysed, results were concordant with the extent of the epigenetic abnormality. Indeed, the soluble form of IGF2R was slightly decreased in plasma and its binding capacity (analysed by binding assay and affinity labelling) was decreased to the same extent.

In summary, epigenetic modifications of IGF2R are not frequently involved in human OGS, but might play a role in a subset of cases. Other mechanisms of inactivation of $I G F 2 R$, such as genetic mutation, are unlikely, as most children with OGS have a normal sIGF2R level. Other mechanisms may cause an OGS by inducing the activity of growth factors and further studies of $11 \mathrm{pl} 5$ genes and other IGF2 related regulators should be carried out to validate this hypothesis.

\section{ACKNOWLEDGEMENTS}

This work was supported by the Assistance Publique Hôpitaux de Paris, the University Paris VI and INSERM (U515).

\section{Authors' affiliations}

C Gicquel, V Gaston, Y Le Bouc, Laboratoire d'Explorations

Fonctionnelles Endocriniennes, Hôpital Trousseau, Assistance PubliqueHôpitaux de Paris, INSERM U515, 75012 Paris, France

J Weiss, C D Scott, Kolling Institute of Medical Research, University of Sydney, Royal North Shore Hospital, St Leonards, New South Wales 2065, Australia

J Amiel, Département de Génétique, Hôpital Necker-Enfants Malades, Assistance Publique-Hôpitaux de Paris, 75015, Paris, France

Correspondence to: $\operatorname{Dr} C$ Gicquel, Laboratoire d'Explorations Fonctionnelles Endocriniennes, Hôpital Trousseau, 26 Avenue Arnold Netter, 75012 Paris, France; christine.gicquel@trs.ap-hop-paris.fr

Received 13 May 2003

Accepted 25 June 2003

\section{REFERENCES}

1 Li M, Squire JA, Weksberg R. Overgrowth syndromes and genomic imprinting: from mouse to man. Clin Genet 1998;53:165-70.

2 Maher ER, Reik W. Beckwith-Wiedemann syndrome: imprinting in clusters revisited. J Clin Invest 2000;105:247-52.

3 Pilia G, Hughes-Benzie RM, MacKenzie A, Baybayan P, Chen EY, Huber R, Neri G, Cao A, Forabosco A, Schlessinger D. Mutations in GPC3, a glypican gene, cause the Simpson-Golabi-Behmel overgrowth syndrome. Nat Genet 1996;12:241-7.

$4 \mathrm{Xu}$ Y, Papageorgiou A, Polychronakos C. Developmental regulation of the soluble form of insulin-like growth factor-II/mannose 6-phosphate receptor in human serum and amniotic fluid. J Clin Endocrinol Metab 1998;83:437-42.

5 Filmus J. Glypicans in growth control and cancer. Glycobiology 2001;11:19R-23R.

6 Selleck SB. Overgrowth syndromes and the regulation of signaling complexes by proteoglycans. Am J Hum Genet 1999;64:372-7.

7 Braulke T. Type-2 IGF receptor: a multi-ligand binding protein. Horm Metab Res 1999;31:242-6.

8 Lau M, Steward C, Liu Z, Bhatt H, Rotwein P, Steward C. Loss of the imprinted IGF2/cation-independant mannose 6-phosphate receptor results in fetal overgrowth and perinatal lethality. Genes Dev 1994;8:2953-63.

9 Wang ZQ, Fung MR, Barlow DP, Wagner EF. Regulation of embryonic growth and lysosomal targeting by the imprinted IGF2/MPR gene. Nature 1994;372:464-7

10 Ludwig T, Eggenschwiler J, Fisher P, D'Ercole AJ, Davenport ML, Efstratiadis A. Mouse mutants lacking the type 2 IGF receptor (IGF2R) are rescued from perinatal lethality in IGF2 and IGF1r null backgrounds. Dev Biol 1996;177:517-35

11 Funk B, Kessler U, Eisenmenger W, Hansmann A, Kolb HJ, Kiess W. Expression of the insulin-like growth factor-II/mannose-6-phosphate receptor in multiple human tissues during fetal life and early infancy. J Clin Endocrinol Metab 1992;75:424-31.

12 Senior PV, Byrne S, Brammar WJ, Beck F. Expression of the IGF-II/mannose6-phosphate receptor mRNA and protein in the developing rat. Development 1990; 109:67-73

13 Matzner U, von Figura K, Pohlmann R. Expression of the two mannose 6phosphate receptors is spatially and temporally different during mouse embryogenesis. Development 1992;114:965-72. 
14 Pellegrini M, Pilia G, Pantano S, Lucchini F, Uda M, Fumi M, Cao A, Schlessinger D, Forabosco A. Gpc3 expression correlates with the phenotype of the Simpson-Golabi-Behmel syndrome. Dev Dyn 1998;213:431-9.

15 Barlow DP, Stoger R, Herrmann BG, Saito K, Schweifer N. The mouse insulinlike growth factor type- 2 receptor is imprinted and closely linked to the Tme locus. Nature 1991;349:84-7.

16 Hu JF, Oruganti H, Vu TH, Hoffman AR. Tissue-specific imprinting of the mouse insulin-like growth factor II receptor gene correlates with differential allele-specific DNA methylation. Mol Endocrinol 1998;12:220-32.

17 Xu Y, Goodyer CG, Deal C, Polychronakos C. Functional polymorphism in the parental imprinting of the human IGF2R gene. Biochem Biophys Res Commun 1993; 197:747-54.

18 Riesewijk AM, Xu YQ, Schepens MT, Mariman EM, Polychronakos C, Ropers $\mathrm{HH}$, Kalscheuer VM. Absence of an obvious molecular imprinting mechanism in a human fetus with monoallelic IGF2R expression. Biochem Biophys Res Commun 1998;245:272-7.

19 Oudejans CB, Westerman B, Wouters D, Gooyer S, Leegwater PA, van Wijk IJ, Sleutels F. Allelic IGF2R repression does not correlate with expression of antisense RNA in human extraembryonic tissues. Genomics 2001;73:331-7.

20 Wutz A, Smrzka OW, Barlow DP. Making sense of imprinting the mouse and human IGF2R loci. Novartis Found Symp 1998;214:251-9; discussion 2603.

21 Wutz A, Barlow DP. Imprinting of the mouse IGF2 $r$ gene depends on an intronic CpG island. Mol Cell Endocrinol 1998;140:9-14

22 Killian JK, Nolan CM, Wylie AA, Li T, Vu TH, Hoffman AR, Jirtle RL. Divergent evolution in M6P/IGF2R imprinting from the Jurassic to the Quaternary. Hum Mol Genet 2001; 10:1721-8.

23 Stoger R, Kubicka P, Liu CG, Kafri T, Razin A, Cedar H, Barlow. Maternalspecific methylation of the imprinted mouse IGF2r locus identifies the expressed locus as carrying the imprinting signal. Cell 1993;73:61-71.

24 Smrzka OW, Fae I, Stoger R, Kurzbauer R, Fischer GF, Henn T, Weith A, Barlow DP. Conservation of a maternal-specific methylation signal at the human IGF2R locus. Hum Mol Genet 1995:4:1945-52.

25 Riesewijk AM, Schepens MT, Welch TR, van den Berg-Loonen EM, Mariman EM, Ropers HH, Kalschever VM. Maternal-specific methylation of the human IGF2R gene is not accompanied by allele-specific transcription. Genomics 1996:31:158-66.

26 Wutz A, Smrzka OW, Schweifer N, Schellander K, Wagner EF, Barlow DP. Imprinted expression of the IGF2R gene depends on an intronic CpG island. Nature 1997;389:745-9.

27 Birger $Y$, Shemer R, Perk J, Razin A. The imprinting box of the mouse IGF2r gene. Nature 1999;397:84-8.

28 Hankins GR, De Souza AT, Bentley RC, Patel MR, Marks JR, Iglehart JD, Jirtle RL. M6P/IGF2 receptor: a candidate breast tumor suppressor gene. Oncogene 1996;12:2003-9.

29 Oates AJ, Schumaker LM, Jenkins SB, Pearce AA, DaCosta SA, Arun B, Ellis MJ. The mannose 6-phosphate/insulin-like growth factor 2 receptor (M6P/IGF2R), a putative breast tumor suppressor gene. Breast Cancer Res Treat 1998:47:269-81.

30 De Souza AT, Hankins GR, Washington MK, Fine RL, Orton TC, Jirtle RL. Frequent loss of heterozygosity on 6q at the mannose 6-phosphate/insulin-like growth factor II receptor locus in human hepatocellular tumors. Oncogene 1995; 10:1725-9.

31 De Souza AT, Hankins GR, Washington MK, Orton TC, Jirtle RL. M6P/IGF2R gene is mutated in human hepatocellular carcinomas with loss of heterozygosity. Nat Genet 1995; 11:447-9.

32 Ozturk M. Genetic aspects of hepatocellular carcinogenesis. Semin Liver Dis 1999:19:235-42.

33 O'Gorman DB, Costello M, Weiss J, Firth SM, Scott CD. Decreased insulin-like growth factor-II/mannose 6-phosphate receptor expression enhances tumorigenicity in JEG-3 cells. Cancer Res 1999;59:5692-4.
34 O'Gorman DB, Weiss J, Hettiaratchi A, Firth SM, Scott CD. Insulin-like growth factor-II/mannose 6-phosphate receptor overexpression reduces growth of choriocarcinoma cells in vitro and in vivo. Endocrinology 2002; 143:4287-94

35 Young LE, Fernandes K, McEvoy TG, Butterwith SC, Gutierrez CG, Carolan C, Broadbent PJ, Robinson JJ, Wilmut I, Sinclair KD. Epigenetic change in IGF2R is associated with fetal overgrowth after sheep embryo culture. Nature 2001;27:153-4.

36 Engel JR, Smallwood A, Harper A, Higgins MJ, Oshimura M, Reik W, Schofield PN, Maher ER. Epigenotype-phenotype correlations in BeckwithWiedemann syndrome. J Med Genet 2000;37:921-6.

37 Bliek J, Maas SM, Ruijter JM, Hennekam RC, Alders M, Westerveld A, Mannens MM. Increased tumor risk for BWS patients correlates with aberrant $\mathrm{H} 19$ and not KCNQ1OT1 hypomethylation in familial cases of BWS. Hum Mol Genet 2001; 10:467-76.

38 Gaston V, Le Bouc Y, Soupre V, Burglen L, Donadieu J, Oro H, Audry G, Vazquez MP, Gicquel C. Analysis of the methylation status of the KCNQIOT and $\mathrm{H} 19$ genes in leukocyte DNA for the diagnosis and prognosis of BeckwithWiedemann syndrome. Eur J Hum Genet 2001 ;9:409-18.

39 DeBaun MR, Niemitz EL, McNeil DE, Brandenburg SA, Lee MP, Feinberg AP. Epigenetic alterations of $\mathrm{H} 19$ and LIT1 distinguish patients with BeckwithWiedemann syndrome with cancer and birth defects. Am J Hum Genet 2002;70:604-11.

40 Weksberg R, Nishikawa J, Caluseriu O, Fei YL, Shuman C, Wei C, Steele L, Cameron J, Smith A, Ambus I, Li M, Ray PN, Sadowski P, Squire J. Tumor development in the Beckwith-Wiedemann syndrome is associated with a variety of constitutional molecular 11 p15 alterations including imprinting defects of KCNQ1OT1. Hum Mol Genet 2001;10:2989-3000.

41 Gicquel C, Le Bouc Y, Luton J, Girard F, Bertagna X. Monoclonality of corticotroph macroadenomas in Cushing's disease. J Clin Endocrinol Metab 1992;75:472-5.

42 Grunau C, Clark SJ, Rosenthal A. Bisulfite genomic sequencing: systematic investigation of critical experimental parameters. Nucleic Acids Res 2001;29:E65-5.

43 Costello M, Baxter RC, Scott CD. Regulation of soluble insulin-like growth factor II/mannose 6-phosphate receptor in human serum: measurement by enzyme-linked immunosorbent assay. J Clin Endocrinol Metab 1999;84:611-17.

44 Baxter RC, Brown AS, Turtle JR. Radioimmunoassay for somatomedin C: comparison with radioreceptor assay in patients with growth-hormone disorders, hypothyroidism, and renal failure. Clin Chem 1982;28:488-95.

45 Baxter RC. Radioimmunoassay for insulin-like growth factor (IGF) II: interference by pure IGF-binding proteins. J Immunoassay 1990; 1 1:445-58.

46 Baxter RC, Daughaday W. Impaired formation of the ternary insulin-like growth factor-binding protein complex in patients with hypoglycemia due to non islet cell tumors. J Clin Endocrinol Metab 1991;73:696-702.

47 Leighton PA, Ingram RS, Eggenschwiler J, Efstratiadis A, Tilghman SM. Disruption of imprinting caused by deletion of the $\mathrm{H} 19$ gene region in mice. Nature 1995;375:34-9.

48 Sun F, Dean W, Kelsey G, Allen N, Reik W. Transactivation of IGF2 in a mouse model of Beckwith-Wiedemann syndrome. Nature 1997:389:809-15.

49 Ogawa O, McNoe LA, Eccles MR, Morison IM, Reeve AE. Human insulin-like growth factor type I and type II receptors are not imprinted. Hum Mol Genet 1993;2:2163-5.

50 Kalschever VM, Mariman EC, Schepens MT, Rehder H, Ropers HH. The insulin-like growth factor type-2 receptor gene is imprinted in the mouse but not in humans. Nat Genet 1993;5:74-8.

51 Lyle R, Watanabe D, te Vruchte D, Lerchner W, Smrzka OW, Wutz A, Schageman J, Hahner L, Davies C, Barlow DP. The imprinted antisense RNA at the IGF2r locus overlaps but does not imprint Mas1. Nature 2000;25:19-21.

52 Xu YQ, Grundy P, Polychronakos C. Aberrant imprinting of the insulin-like growth factor II receptor gene in Wilms' tumor. Oncogene 1997;14:1041-6. 